\title{
Bilateral vocal cord paralysis due to direct invasion of right and left recurrent laryngeal nerves in a small cell lung cancer patient
}

\author{
Kohei Horiuchi @ $1{ }^{1,2}{ }^{T}$ oshiki Ikeda, ${ }^{1}$ Amina Kida, ${ }^{3}$ Yoshitaka Oyamada ${ }^{1}$
}

'Department of Respiratory Medicine, Tokyo Medical Center, Meguro-ku, Japan

${ }^{2}$ Department of Internal Medicine, Division of Pulmonary Medicine, Keio University School of Medicine, Shinjuku-ku, Japan ${ }^{3}$ Department of Otolaryngology, Tokyo Medical Center, Meguroku, Japan

\section{Correspondence to}

Dr Kohei Horiuchi;

kohei.horiuchi17@gmail.com

Accepted 27 July 2021
A 67-year-old man presented to our department with a 2-day history of dyspnoea and worsening voice hoarseness. He had a smoking history of 92 pack-years, and had been on chemotherapy for extensive small cell lung cancer for 7 months. His treatment history was complicated by a right vocal cord paralysis confirmed laryngoscopically 2 months prior to consultation, and voice hoarseness persisted thereafter. At that time, the right recurrent laryngeal nerve injury was suspected to have been caused by a mass lesion located near the right subclavian artery (figure 1A). On arrival, vital signs and physical examination yielded unremarkable findings, without any signs of stridor or lung crackles. Careful inspection of the CT of the chest revealed progression of mass lesions under the aortic arch, which was suggestive of a left recurrent laryngeal nerve injury (figure 1B). Laryngoscopy revealed both vocal cords in the paramedian position with minimal symmetrical mobility and the presence of a phonation gap, indicating bilateral vocal cord paralysis (BVCP) (figure 2). Subsequently, he continued with another chemotherapy without any intervention, as the vocal cords were fixed open, which would unlikely lead to upper airway obstruction. Monthly laryngoscopy revealed no improvement in the mobility of the vocal cords. Finally, he died due to pneumonia after 2 months postdiagnosis of BVCP.

BVCP is a rarely reported condition in malignancies. Some of its reported mechanisms include paraneoplastic neuropathy, iatrogenic injuries such as surgical complications and immune-related

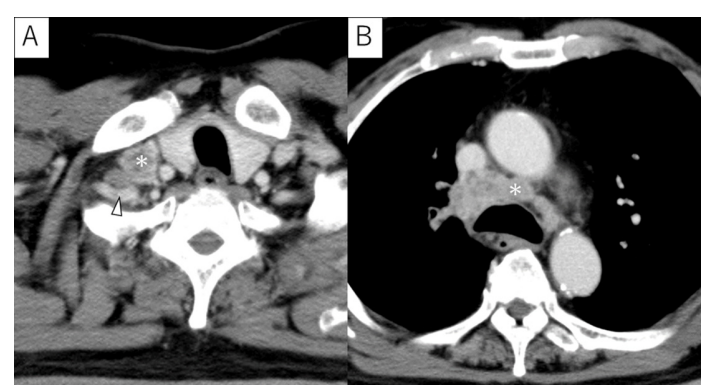

Limited 2021. No commercial re-use. See rights and permissions. Published by BMJ.

To cite: Horiuchi $K$, Ikeda T, Kida $\mathrm{A}$, et al. BMJ Case Rep 2021;14:e245011. doi:10.1136/bcr-2021245011

Figure 1 A CT slice showing a mass lesion (white star) located near the right subclavian artery (white arrowhead), obstructing the right recurrent laryngeal nerve (A). A CT slice showing multiple mass lesions (white star) located under the aortic arch, obstructing the left

\section{DESCRIPTION}

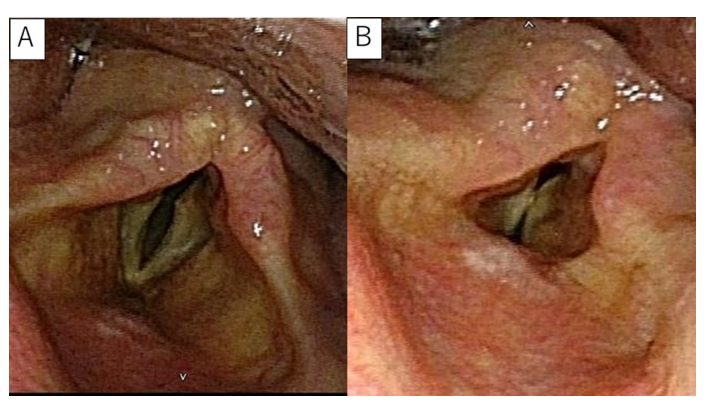

Figure 2 Laryngoscopy images revealing bilateral vocal cords in the paramedian position with minimal symmetrical mobility $(A)$ and the presence of a phonation gap (B), indicating bilateral vocal cord paralysis.

adverse events due to immune checkpoint inhibitors. ${ }^{1-3}$ However, in our case, BVCP was due to the direct invasion of both recurrent laryngeal nerves by separate lesions at different onsets, a condition rarely reported in the literature. It is important to understand that the recurrent laryngeal nerves loop at different levels: at the subclavian artery for the right and the aortic arch for the left. ${ }^{4}$ Additionally, this aetiology is distinguishable from other mechanisms due to the unique progression pattern of voice hoarseness, which occurs in a stepwise manner, as described herein. Moreover, BVCP is a serious condition that may be fatal due to airway obstruction. ${ }^{5}$ Although we could not predict this patient's BVCP, he was fortunate to have his airway preserved. For such cases, a careful investigation of the underlying cause of the vocal cord paralysis and awareness of the potential future risk of BVCP is beneficial, as it may enable clinicians to discuss possibilities of future conditions with the patient. For a patient largely at risk for upper

\section{Learning points}

A rare case of bilateral vocal cord paralysis (BVCP) was reported in a small cell lung cancer patient, caused by the direct invasion of both recurrent laryngeal nerves by separate lesions at different onsets. recurrent laryngeal nerve (B). 
airway obstruction, surgical interventions such as tracheostomy or cordotomy, as well as botulinum toxin injection, may be performed. In this case, we mainly continued with the clinical course considering the highly invasive nature of the procedures. When clinicians encounter a lung cancer patient with unilateral vocal cord paralysis, it is critical to search for lesions obstructing the contralateral recurrent laryngeal nerve to assess the future risk of BVCP and discuss airway management in advance.

Contributors $\mathrm{KH}, \mathrm{Tl}$ and $\mathrm{AK}$ provided patient care. $\mathrm{KH}$ wrote the initial draft of the manuscript. YO supervised the study and suggested critical revisions regarding important intellectual content. All authors approved the final version as submitted to the journal.

Funding The authors have not declared a specific grant for this research from any funding agency in the public, commercial or not-for-profit sectors.

Competing interests None declared.

Patient consent for publication Obtained.
Provenance and peer review Not commissioned; externally peer reviewed.

\section{ORCID iD}

Kohei Horiuchi http://orcid.org/0000-0002-9396-7813

\section{REFERENCES}

1 Yeung JC, Pringle CE, Sekhon HS, et al. Bilateral vocal cord paralysis and cervicolumbar radiculopathy as the presenting paraneoplastic manifestations of small cell lung cancer: a case report and literature review. Case Rep Otolaryngol 2016;2016:1-5.

2 Sagawa M, Donjo T, Isobe T, et al. Bilateral vocal cord paralysis after lung cancer surgery with a double-lumen endotracheal tube: a life-threatening complication. J Cardiothorac Vasc Anesth 2006;20:225-6.

3 Willegers T, Janssen JBE, Boers-Sonderen MJ, et al. Bilateral vocal cord paralysis due to an immune-related adverse event of nivolumab: a case report. J Immunother 2020;43:93-4.

4 Williamson AJ, Shermetaro C. Unilateral vocal cord paralysis. In: StatPearls [Internet] Treasure Island (FL). StatPearls Publishing, 2021.

5 Soong CM, Adair R. A rare cause of adult-onset bilateral vocal cord paralysis. BMJ Case Rep 2021;14:e239354

Copyright 2021 BMJ Publishing Group. All rights reserved. For permission to reuse any of this content visit https://www.bmj.com/company/products-services/rights-and-licensing/permissions/

BMJ Case Report Fellows may re-use this article for personal use and teaching without any further permission.

Become a Fellow of BMJ Case Reports today and you can:

- Submit as many cases as you like

- Enjoy fast sympathetic peer review and rapid publication of accepted articles

- Access all the published articles

- Re-use any of the published material for personal use and teaching without further permission

\section{Customer Service}

If you have any further queries about your subscription, please contact our customer services team on +44 (0) 2071111105 or via email at support@bmj.com.

Visit casereports.bmj.com for more articles like this and to become a Fellow 